\title{
SINTESIS HIDROKSIAPATIT DARI TULANG SAPI DENGAN METODE BASAH PADA BERBAGAI WAKTU PENGADUKAN DAN SUHU SINTERING
}

\author{
[Synthesis of Hydroxyapatite from Cow Bones Under Wet Method at Various of \\ Stirring Times and Sintering Temperatures] \\ Reflin Yuliana ${ }^{{ }^{\star}}$, Erwin Abdul Rahim ${ }^{1}$, Jaya Hardi ${ }^{1}$ \\ ${ }^{1}$ Jurusan Kimia Fakultas MIPA, Universitas Tadulako \\ Jl. Soekarno Hatta Km.9, Kampus Bumi Tadulako Tondo Palu, Telp. 0451- 422611 \\ *)Coresponding author: reflin.yulianadongalemba@yahoo.com
}

Diterima 7 Juni 2017, Disetujui 21 Agustus 2017

\begin{abstract}
Synthesis of hydroxyapatite (HAp) can be obtained from a reaction between calcium of cow bones and phosphate under wet method. Completely Random Design (CRD) was used in this research with three levels of stirring time and four levels of sintering temperature i.e. 60, 90, 120 minutes and $800^{\circ} \mathrm{C}, 850^{\circ} \mathrm{C}, 900^{\circ} \mathrm{C}, 950^{\circ} \mathrm{C}$, respectively. The result showed that synthesis reaction at the sintering temperature of $850^{\circ} \mathrm{C}$ for 120 minutes were the best conditions to produce HAp. The yield of HAp product in those conditions was $48,5 \%$. XRD spectrum of HAp had the highest intensity of 1000 at a $2 \Theta$ angel of $31.78^{\circ}$.
\end{abstract}

Keywords : Hydroxyapatite, Stirring Time, Sintering Temperature, Cow Bone

\begin{abstract}
ABSTRAK
Sintesis hidroksiapatit (HAp) dapat diperoleh dari reaksi antara kalsium dari tulang sapi dan fosfat dengan menggunakan metode basah. Penelitian ini dilakukan dengan menggunakan rancangan acak lengkap (RAL), dengan variasi waktu pengadukan 60, 90, dan 120 menit dan variasi suhu sintering $800^{\circ} \mathrm{C}, 850^{\circ} \mathrm{C}, 900^{\circ}$, dan $950^{\circ} \mathrm{C}$. Hasil penelitian menunjukkan bahwa sintesis pada suhu sintering $850^{\circ} \mathrm{C}$ selama pengadukan 120 menit merupakan kondisi terbaik untuk memproduksi Hap. Yield dari HAp dari kondisi tersebut adalah $48,5 \%$ dan spektrum XRD menunjukkan intensitas tertinggi (1000) pada sudut $2 \Theta 31,78^{\circ}$.
\end{abstract}

Kata kunci : Hidroksiapatit, Waktu pengadukan, Suhu Sintering, Tulang Sapi 


\section{LATAR BELAKANG}

Sapi merupakan salah satu hewan yang banyak diternakkan di Indonesia dan pada tahun 2011, jumlah pemotongannya adalah 1.519.178 ekor (BPS, 2011). Besarnya jumlah pemotongan tersebut sejalan dengan banyaknya limbah yang dihasilkan, salah satunya adalah tulang. Tulang sapi selama ini banyak dimanfaatkan sebagai bahan baku kerajinan dan pembuatan tepung sebagai pelengkap mineral dalam pembuatan pakan ikan. Tulang sapi mengandung komposisi mineral berupa unsur kalsium dan fosfor. Kalsium yang terkandung dalam tulang sapi adalah sebesar 7,07\% dalam bentuk senyawa $\mathrm{CaCO}_{3}, 1,96 \%$ dalam bentuk senyawa $\mathrm{CaF}_{2}$, fosfor sebanyak 2,09\% dalam bentuk senyawa $\mathrm{Mg}_{3}\left(\mathrm{PO}_{4}\right)_{2}$, dan 58,30\% dalam bentuk senyawa $\mathrm{Ca}_{3}\left(\mathrm{PO}_{4}\right)_{2}$ (Perwitasari, 2008). Kandungan kalsium dan fosfor tersebut dapat dimanfaatkan sebagai bahan baku utama pada sintesis biokeramik hidroksiapatit.

Hidroksiapatit (HAp) dengan rumus kimia $\quad \mathrm{Ca}_{10}\left(\mathrm{PO}_{4}\right)_{6}(\mathrm{OH})_{2} \quad$ merupakan material biokeramik yang dapat digunakan sebagai pengganti tulang buatan yang diimplankan ke dalam tubuh manusia. Meskipun jaringan tulang manusia memiliki kemampuan sangat baik dalam beregenerasi, tetapi jika kerusakan cukup parah, maka pencangkokkan tulang sulit untuk dilakukan, sehingga penggunaan hidroksiapatit dapat menjadi solusi (Sopyan \& Mel., 2007).
Beberapa peneliti telah melakukan sintesis material ini pada temperatur yang berbeda-beda. Vaidya et al. (1997) melakukan sinter hidroksiapatit dari pada kisaran temperatur $800<\mathrm{T}<1400^{\circ} \mathrm{C}$ selama 4 hingga 6 jam, sedangkan Gomes et al. (2008), melakukan sinter hidroksiapatit pada temperatur $500-800^{\circ} \mathrm{C}$ selama 1 jam. Terdapat dua struktur kristal yang berbeda pada hidroksiapatit yakni monoklinik dan heksagonal. Elliot et al. (1973) melaporkan bahwa struktur hidroksiapatit monoklinik diperoleh hanya pada kondisi murni dan komposisi stoikiometrik (rasio Ca/P 1,67).

Sintesis hidroksiapatit dari tulang sapi telah dilakukan menggunakan metode kering (Wathi et al. 2014) dan metode Sol-Gel (Pinangsih et al., 2014). Pada metode kering, didapatkan rendemen hidroksiapatit tertinggi yaitu $91,625 \%$ pada perbandingan massa Ca:P sebesar 1:0,065 (Wathi et al. 2014). Selain kedua metode tersebut, metode lain yang dapat digunakan untuk mensintesis HAp dari tulang sapi yaitu dengan menggunakan metode basah. Penggunaan metode basah ini memiliki kelebihan, yaitu biaya yang relatif murah, dan dalam prosesnya akan menghasilkan hidroksiapatit dengan tingkat kemurnian yang cukup tinggi. Wahdah \& Darjito (2014) melaporkan rendemen HAp dari tulang sapi dengan metode basah suhu sinter $800{ }^{\circ} \mathrm{C}$ adalah 62,78 \%. Hasil tersebut masih jauh di bawah rendemen HAp dengan metode kering, sehingga 
perlu dikaji penggunaan beberapa suhu sinter. Suryadi (2011), menggunakan suhu sinter yang bervariasi dengan tingkat kristanilitas tertinggi diperoleh pada suhu sinter $900^{\circ} \mathrm{C}$. Selain faktor suhu sinter, rendemen HAp juga dipengaruhi oleh waktu pengadukan. Ningsih et al. (2014) melaporkan bahwa sintesis hidroksiapatit dari cangkang keong kepah yang dilakukan pada waktu pengadukan selama 90 menit dan suhu sinter $500^{\circ} \mathrm{C}$ memperoleh rendemen sebesar $71 \%$. Berdasarkan hal tersebut, maka perlu dilakukan kajian pada sintesis hidroksiapatit dari tulang sapi dengan metode basah pada berbagai waktu pengadukan dan suhu sinter.

\section{METODE PENELITIAN}

\section{Bahan dan Peralatan}

Alat yang digunakan terdiri dari wadah plastik, autoklaf Himarayana neraca analitik (Ohaus), tanur (Nebertherm), oven (Memmer), hot plate, pengaduk magnetik, desikator, AAS, XRD, FTIR (Tipe ATR Bruker) dan alat-alat gelas dilaboratorium kimia.

Bahan yang digunakan terdiri dari tulang sapi, larutan $\mathrm{NaOH} 0,1 \%$, larutan aseton, larutan $\mathrm{K}_{2} \mathrm{Cr}_{2} \mathrm{O}_{7}$, larutan $\mathrm{H}_{2} \mathrm{SO}_{4}$, larutan $\left(\mathrm{NH}_{4}\right)_{2} \mathrm{HPO}_{4}$ dan air akuadest.

\section{Prosedur Penelitian}

Preparasi $\mathrm{Ca}(\mathrm{OH})_{2}$ Dari Tulang Sapi (Modifikasi metode Pianingsih et al., 2014)

Tulang sapi yang telah ditentukan kadar kalsiumnya (Metode Desy, 2014) sebanyak $1 \mathrm{~kg}$ dibersihkan dan direbus dalam autoklaf pada suhu $150^{\circ} \mathrm{C}$ tekanan 2 atm. Kemudian direndam dalam $1 \mathrm{~L}$ larutan $\mathrm{NaOH} 0,1 \%$ selama 7 jam dalam wadah plastik. Selanjutnya, ditiriskan dan direndam dengan $1 \mathrm{~L}$ aseton dalam wadah plastik. Setelah 8 jam, tulang ditiriskan dan dijemur di bawah sinar matahari. Tahap berikutnya, tulang sapi kering dipanaskan pada temperatur 1000 ${ }^{\circ} \mathrm{C}$ selama 6 jam untuk menghasilkan senyawa $\mathrm{CaO}$. Serbuk $\mathrm{CaO}$ dibiarkan kontak dengan udara selama seminggu pada suhu ruang agar membentuk senyawa $\mathrm{Ca}(\mathrm{OH})_{2}$.

Sintesis HAp dengan Metode Basah (Modifikasi metode Ningsih et al., 2014)

Suspensi $\mathrm{Ca}(\mathrm{OH})_{2} \quad 0.5 \mathrm{M}$ disiapkan dari serbuk $\mathrm{Ca}(\mathrm{OH})_{2}$ (abu hasil kalsinasi yang telah dihidrasi). $100 \mathrm{ml}$ larutan $\left(\mathrm{NH}_{4}\right)_{2} \mathrm{HPO}_{4}$ 0.3 $\mathrm{M}$ ditambahkan ke dalam $100 \mathrm{ml}$ suspensi $\mathrm{Ca}(\mathrm{OH})_{2}$, dengan cara dititrasi secara perlahan pada suhu $42^{\circ} \mathrm{C}$ sambil diaduk dengan pengaduk megnetik. Setelah $(\mathrm{NH})_{2} \mathrm{HPO}_{4}$ habis diteteskan, campuran kemudian didiamkan selama 1 jam pada temperatur $90^{\circ} \mathrm{C}$. Kemudian pada suhu yang sama, campuran diaduk pada waktu sesuai perlakuan. Setelah pengadukan selesai, $\mathrm{pH}$ dari campuran tersebut disesuaikan menjadi 10 dengan menambahkan sejumlah larutan $\mathrm{NaOH} 10 \%$. Kemudian campuran didiamkan pada suhu kamar selama 24 jam agar endapan HAp dapat terbentuk. Endapan kemudian disaring dan dicuci menggunakan air destilat 
sebanyak 3 kali. Setelah itu, endapan ditempatkan ke dalam cawan petri untuk dikeringkan. Pada suhu $60^{\circ} \mathrm{C}$ selama 24 jam. Selanjutnya dilakukan proses sintering terhadap HAp pada temperatur $900^{\circ} \mathrm{C}$ selama 6 jam. HAp yang diperoleh selanjutnya didinginkan dalam desikator. Setelah dingin dilakukan pencirian dengan menggunakan XRD. HAp dengan tingkat kristanilitas dan rendemen tertinggi digunakan pada penentuan suhu sinter terbaik dengan perlakuan yang sama menggunakan suhu sinter sesuai perlakuan.

\section{HASIL DAN PEMBAHASAN}

\section{Hidroksiapatit Hasil Sintesis pada Berbagai Waktu Pengadukan}

Tulang sapi yang telah dikalsinasi pada suhu $1000^{\circ} \mathrm{C}$ menghasilkan abu tulang sapi. Perubahan kalsium karbonat menjadi kalsium oksida terjadi selama proses kalsinasi tersebut (reaksi a). Kalsium oksida yang dibiarkan pada udara terbuka akan bereaksi dengan uap air untuk membentuk kalsium hidroksida yang dikenal sebagai proses hidrasi (b).
a) $\mathrm{CaCO}_{3} \rightarrow \mathrm{CaO}+\mathrm{CO}_{2}$
b) $2 \mathrm{CaO}+2 \mathrm{H}_{2} \mathrm{O} \rightarrow 2 \mathrm{Ca}(\mathrm{OH})_{2}$

Hasil analisis menunjukkan bahwa kadar kalsium yang terdapat pada serbuk tulang sapi adalah $31,48 \%$.

Sintesis hidroksiapatit pada penelitian ini menggunakan metode basah. Keunggulan metode basah didasari oleh ketersediaan alat yang dapat di gunakan, biaya yang relatif murah, serta dalam prosesnya akan menghasilkan hidroksiapatit dengan tingkat kemurnian yang cukup tinggi dangan hasil samping berupa air (Vijayalakshmi dan Rajeswari, 2006). Sumber kalsium diperoleh dari tulang sapi yang dihidrasi membentuk $\mathrm{Ca}(\mathrm{OH})_{2}$ direaksikan dengan diamonium hidroksi fosfat sebagai sumber fosfor. Endapan Hap didapatkan setelah didiamkan selama 24 jam (proses aging) pada suhu ruang. Reaksi pembentuk apatit sebagai berikut :

$10 \mathrm{Ca}(\mathrm{OH})_{2}+6\left(\mathrm{NH}_{4}\right)_{2} \cdot \mathrm{HPO}_{4} \rightarrow$

$$
\mathrm{Ca}_{10}\left(\mathrm{PO}_{4}\right)_{6}(\mathrm{OH})_{2}+6 \mathrm{H}_{2} \mathrm{O}+12 \mathrm{NH}_{4} \mathrm{OH}
$$

Waktu pengadukan pada saat sintesis mempengaruhi presentase hidroksiapatit yang terbentuk (Gambar 1).

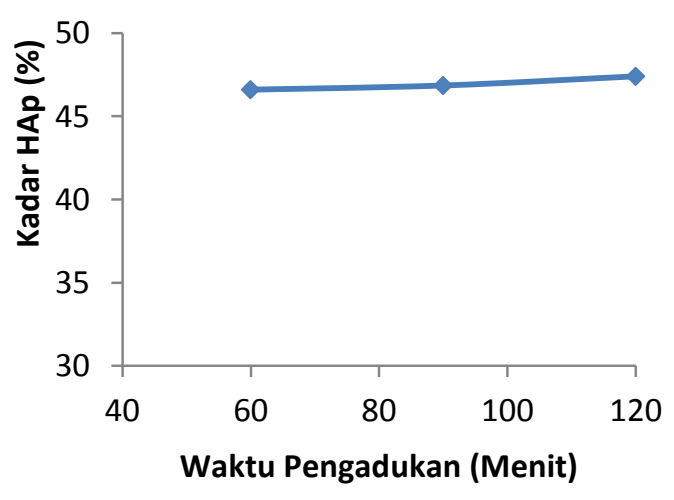

Gambar 1. Pengaruh waktu pengadukan terhadap rendemen HAp

Gambar 1 menunjukkan bahwa semakin lama waktu pengadukan maka rendemen HAp semakin tinggi. Dengan kata lain waktu pengadukan berbanding lurus dengan rendemen HAp. Rendemen HAp pada waktu 60, 90, dan 120 menit berturut-turut $46,6 \%$; $46,85 \%$; dan $47,2 \%$. 


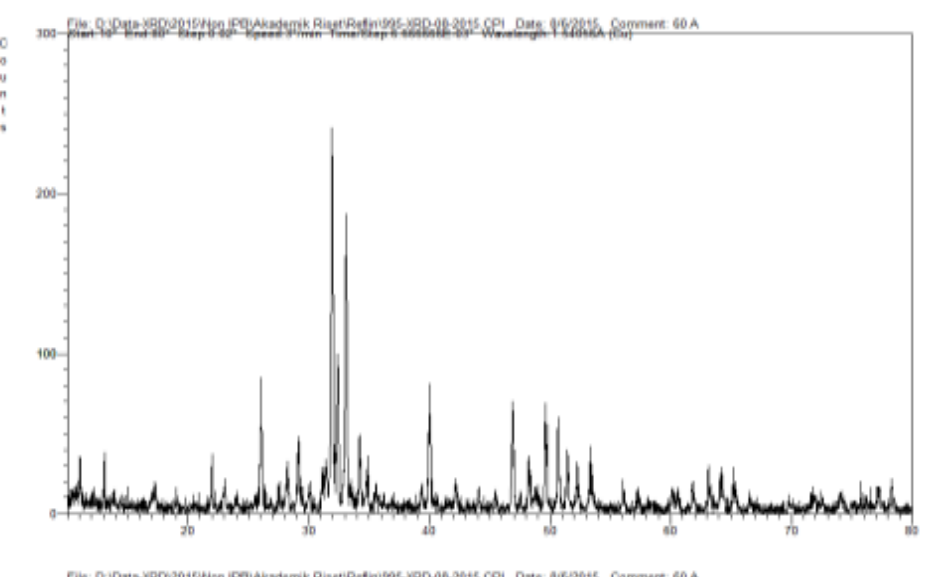

(a)

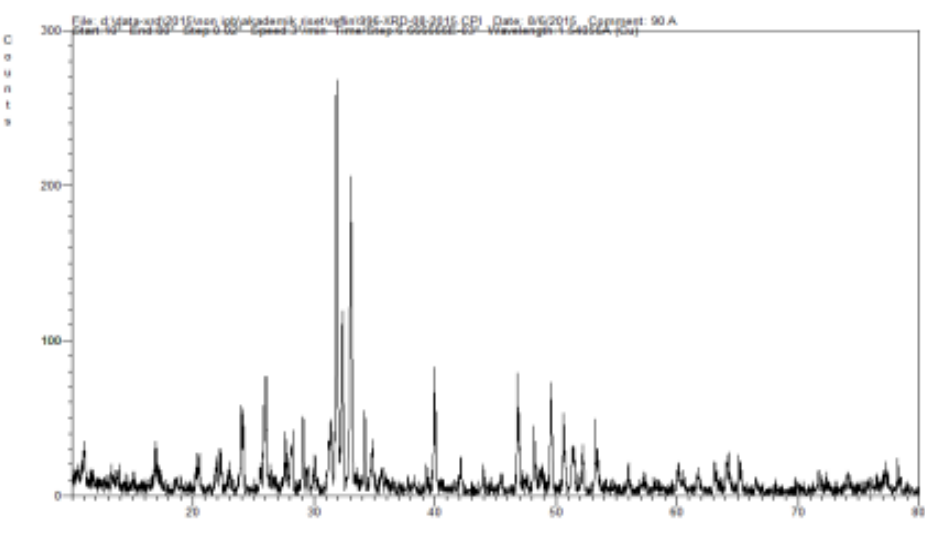

(b)

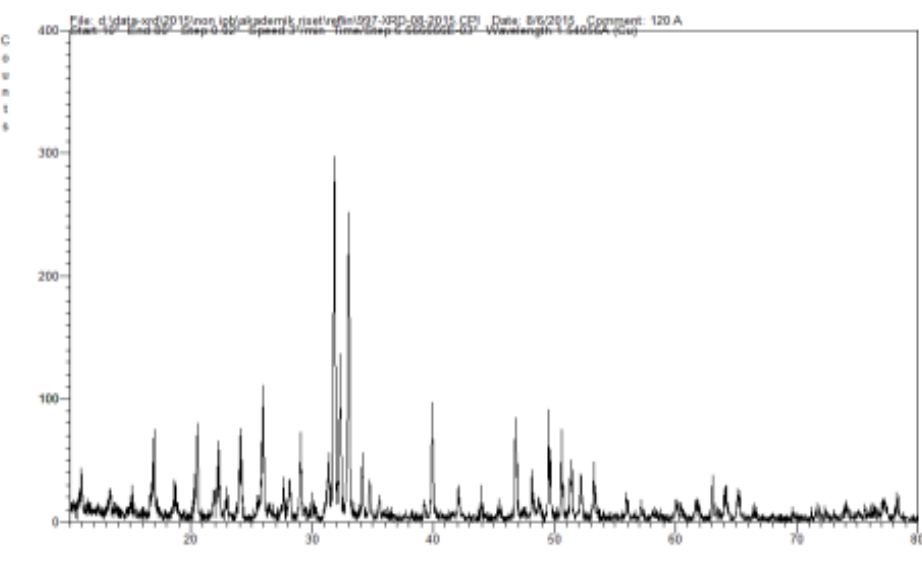

(c)

Gambar 2 Difraktogram Sinar-X HAp pengadukan (a) 60 menit (b) 90 menit (c) 120 menit.

Ningsih et al., (2014) yang besarnya rendemen hidroksiapatit yang mensintesis hidroksiapatit dari cangkang dihasilkan. Hal ini disebabkan karena kerang kepah dengan variasi waktu semakin lama waktu reaksi maka semakin pengadukan, menyatakan bahwa lamanya lama pula waktu tumbukan antar partikel waktu pengadukan berpengaruh pada pereaksi yang menyebabkan semakin 
banyak produk HAp yang terbentuk (Raymond, 2005).

Pola difraksi hidroksiapatit untuk pengadukan 60, 90, dan 120 menit memiliki posisi $2 \Theta$ yang hampir sama dan memiliki intensitas puncak yang tinggi pada $31,92^{\circ}, 31,86^{\circ}$, dan $31,84^{\circ}$ (Gambar 2). Menurut Saryati et al. (2012), fase HAp dicirikan pada intensitas tinggi pada nilai $2 \Theta$ sebesar $31.773^{\circ}, 32.196^{\circ}, 32.902^{\circ}$ dan $34.048^{\circ}$.

Berdasarkan Gambar 2 pola difraksi hidroksiapatit yang dihasilkan untuk pengadukan 60, 90, dan 120 menit yang menempati posisi $2 \theta$ tertinggi masingmasing memiliki intensitas puncak 238, 268, dan 297 . Lama pengadukan 120 menit memiliki intensitas tertinggi (297) pada nilai $2 \theta 31.84^{\circ}$. Daerah kristalinitas hidroksiapatit dapat dilihat pada tingginya intensitas dan lebar setengah puncak pada pola difraksi. Purnama (2006) menyatakan bahwa semakin tinggi intensitas puncak, semakin sempit lebar setengah puncak, maka semakin tinggi kristalinitas hidroksiapatit.

\section{Hidroksiapatit Hasil Sintesis pada Berbagai Suhu Sintering}

Sintesis hidroksiapatit dengan metode basah pada suhu sintering 800 , 850, 900, dan $950^{\circ} \mathrm{C}$ memiliki kecenderungan menghasilkan Hap dengan kadar yang semakin rendah (Gambar 3).

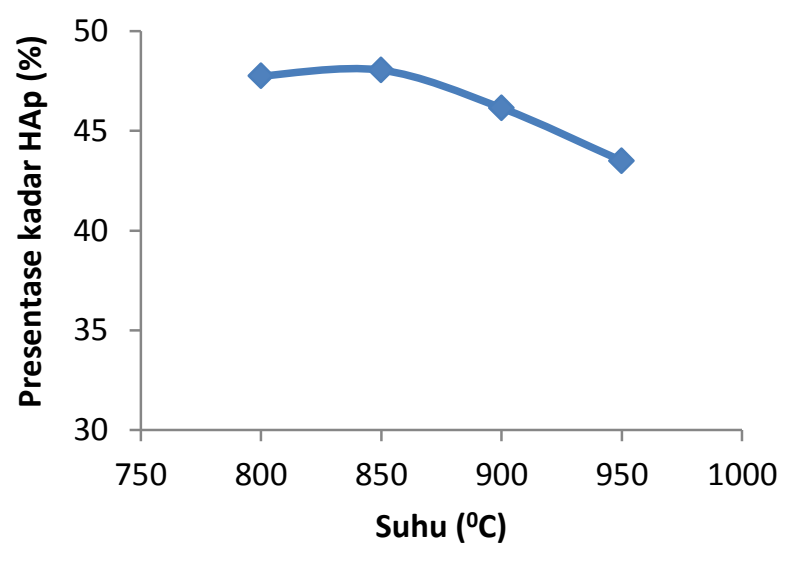

Gambar 3. Pengaruh suhu sintering terhadap rendemen HAp

Suhu sintering $850^{\circ} \mathrm{C}$ memiliki rendemen HAp tertinggi 48,05\%, sedangkan pada suhu 800, 900 dan $950^{\circ} \mathrm{C}$ menghasilkan rendemen masingmasing 46,75\%; 46,15\%; dan $43,5 \%$ (Gambar 3). Penurunan rendemen pada proses sintering diduga karena hilangnya kandungan air dan bahan organik yang terdapat pada bahan serbuk tulang sapi (Al-Sokanee et al., 2009). Wahdah \& Darjito (2014) melaporkan bahwa rendemen HAp dari tulang sapi dengan metode basah sebesar $62,78 \%$ pada suhu sintering $800^{\circ} \mathrm{C}$.

Hasil pengujian XRD menunjukkan bahwa terjadi perubahan intensitas dari puncak-puncak pada difraktogram. Pengaruh temperatur erat kaitannya dengan tingkat kristalinitas dari sampel. Masing-masing temperatur memiliki kenaikan puncak-puncak intensitas kristalinitas yang berbeda-beda (Gambar 4). 


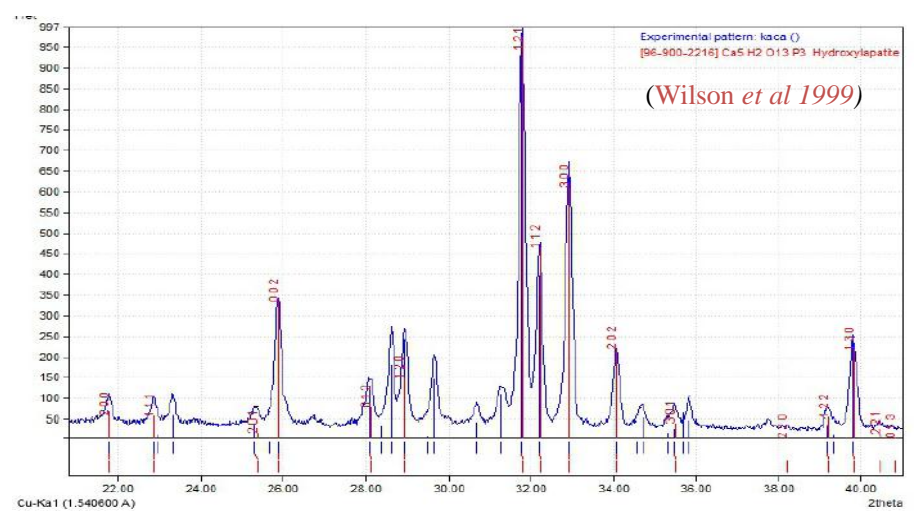

(a)

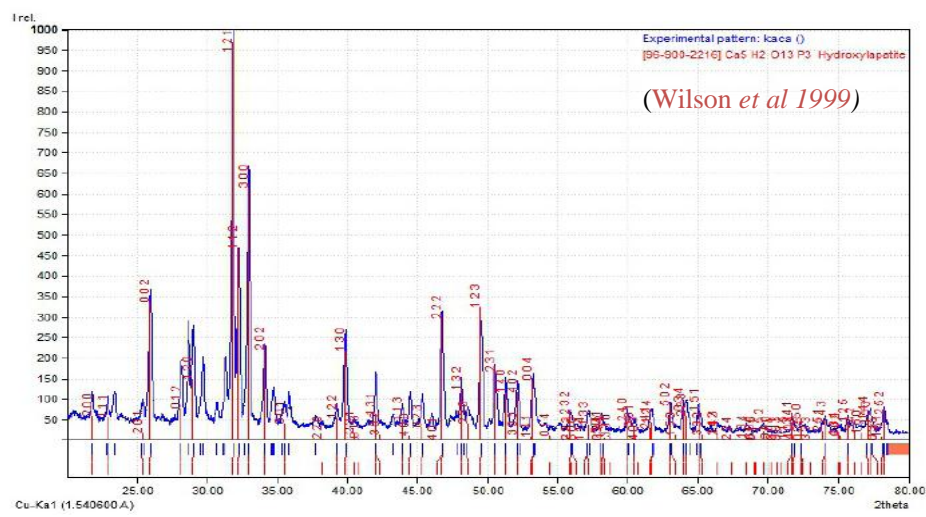

(b)

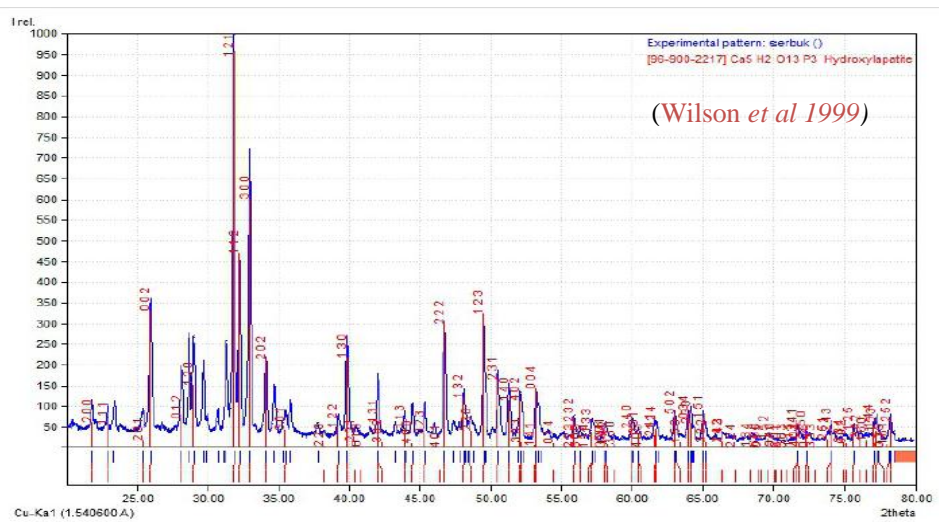

(c)

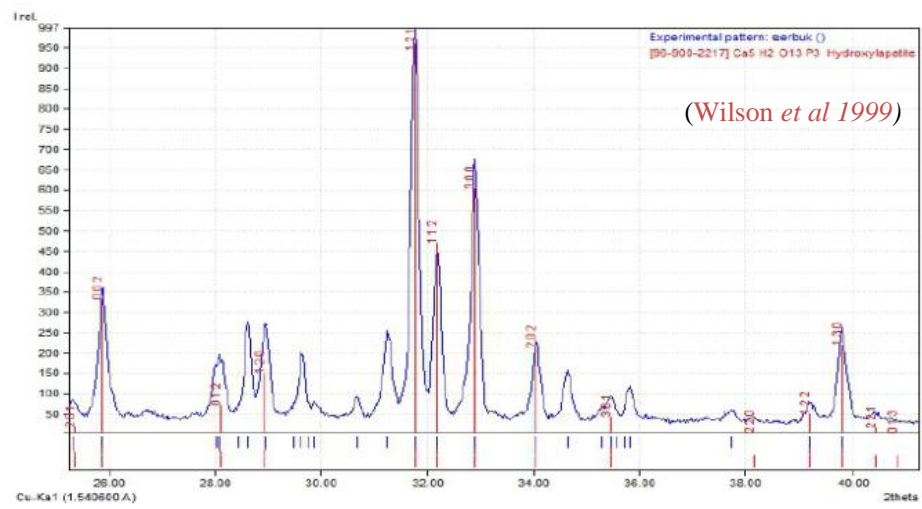

(d)

Gambar 4 Difraktogram XRD HAp Sintesis pada Suhu (a) 800 (b) 850 (c) 900 (d) $950^{\circ} \mathrm{C}$. 
Difraktogram yang memiliki kristalinitas tinggi akan memiliki puncakpuncak dengan intensitas yang tinggi, seperti terlihat pada suhu $850^{\circ} \mathrm{C}$, sudut $2 \theta$ $31.78^{\circ}$ menghasilkan intensitas 1000 , sementara suhu 800,900 dan $950^{\circ} \mathrm{C}$ masing-masing menghasilkan intensitas 978,65; 935,36; dan 1000 pada masingmasing sudut $2 \Theta 31,78^{\circ} ; 31,87^{\circ}$; dan $31,76^{\circ}$. Suryadi (2011) menyatakan bahwa kristalinitas akan semakin tinggi dengan menaikkan temperatur yang digunakan pada proses sintering.

Hidroksiapatit hasil sintesis pada waktu pengadukan 120 menit dan suhu sintering $850^{\circ} \mathrm{C}$ dianalisis dengan FTIR untuk memperkuat dugaan bahwa hidroksiapatit yang telah disintesis dengan metode basah.

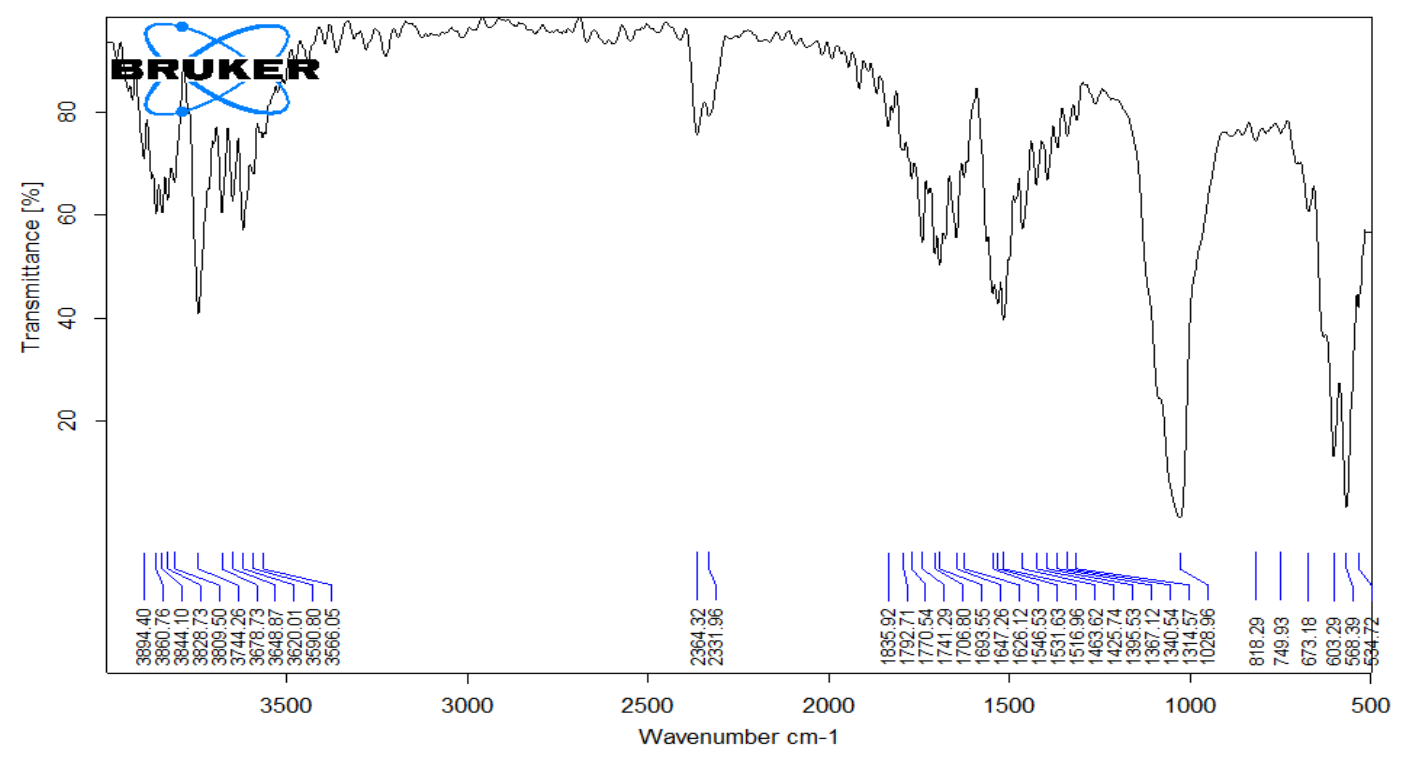

Gambar 5 Spektrum FTIR HAp Sintesis

Berdasarkan spektrum FTIR, gugus $\mathrm{PO}_{4}{ }^{3-}$ memiliki intensitas yang tinggi pada bilangan gelombang 568,39 $\mathrm{cm}^{-1}$ dan $603,29 \mathrm{~cm}^{-1}$ yang merupakan vibrasi tekuk asimetri dan vibrasi ulur asimetri terdeteksi pada bilangan gelombang $1028,96 \mathrm{~cm}^{-1}$. Gugus Ca-O dengan vibrasi ulur asimetri terdeteksi pada bilangan gelombang 1425,74 cm $\mathrm{cm}^{-1}, 1463,62 \mathrm{~cm}^{-1}$; $1516,96 \mathrm{~cm}^{-1}$; dan 1546,53 $\mathrm{cm}^{-1}$. Gugus hidroksil $(\mathrm{OH})$ terdeteksi pada bilangan gelombang 3566,05 $\mathrm{cm}^{-1}$. Hasil serupa pada penelitian Pattanayak et al. (2005) bahwa HAp memliki gugus $\mathrm{Ca}-\mathrm{O}$ yang terdeteksi pada gelombang $1400 \mathrm{~cm}^{-1}$ $1700 \mathrm{~cm}^{-1}$ dan gugus hidroksil (OH) terdeteksi pada bilangan gelombang $3569,99 \mathrm{~cm}^{-1}$.

\section{KESIMPULAN}

Waktu pengadukan 120 menit dan suhu sintering $850^{\circ} \mathrm{C}$ menghasilkan rendemen hidroksiapatit tertinggi, yaitu $48,05 \%$ dengan intensitas difraktogram tertinggi (1000) pada sudut $2 \Theta 31,78^{\circ}$. 
UCAPAN TERIMA KASIH

Secara khusus peneliti menyampaikan ucapan terima kasih kepada Ibu Masta Laboran Dinas Kesehatan dan Laboran Fisika FMIPA UNHAS.

\section{DAFTAR PUSTAKA}

Al-Sokanee ZN, AAK Toabi, MJ Al-Assadi, EA Al-Assadi. 2009. The drug release study of cefi riaxone from porous hydroxyapatite scaff olds. AAPS pharmacy Science Technology. 10(5): 772-779.

Badan Pusat Statistik. 2011. Jumlah Ternak yang Dipotong di Rumah Potong Hewan dan Di Luar Rumah Potong Hewan yang Dilaporkan (Ekor) $2000 \quad$ - 2012, (http://www.bps.go.id/tab sub/view.p hp?kat=3\&tabel=1\&daf\%09tar1\&id subyak $=24 \%$ notab $=13$, diakses tanggl 20 September 2013)

Desy K.F. 2014. Sintesis Hidroksiapatit dari Cangkang Keong Sawah (Bellamya javanica) dengan Metode Basah dan Modifikasi Pori dengan Kitosan. (Skripsi). Bogor: Jurusan Kimia. FMIPA. Institut Pertanian Bogor.

Elliott J. C., Mackie P. E., Young R. A. Monoclinic Hydroxyapatite. Science. 180 (4090): 1055-1057.

Gomes J. F., C. Cristina., Silva., A. Miguel A., Hoyos., S Milton ., Rodrigo, Vieira. 2008. Teresa An Investigation of the Synthesis Parameters of the Reaction of Hydroxyapatite Precipitation in Aqueous Media. International Journal of Chemical Reactor Engineering. (6): 103.

Ningsih R, Nelly, L Destiarti. 2014. Sintesis Hidroksiapatit Dari
Cangkang Kerang Kepah (Polymesoda Erosa) Dengan Variasi Waktu Pengadukan. JKK, 3(1): 2226.

Raymond. 2005. Kimia Dasar KonsepKonsep Inti Edisi Ketiga Jilid 2. Jakarta: Erlangga.

Saryati, S Sulistiyoso., H Ari., Supardi, U Puji dan S Bambang. 2012. Hidroksiapatit Berpori dari Kulit Kerang. (Abstrak). Jurnal Sains Materi Indonesia (JSMI).

Suryadi. 2011. Sintesis dan Karekterisasi Biomaterial Hidroksiapatit dengan Proses Pengendapan Basah. [Tesis]. Depok: Fakultas Teknik. Universitas Indonesia

Sopyan dan Mel. 2007. Porous hidroxyapatite for artificial bone application. SciTech Adv Mater. (8) : 116-123.

Pattanayak, D.K., P Divya., S Upadhyay., C Prasad., B Rao and R Mohan. 2005. Synthesis and Evaluation of Hydroxyapatite Ceramics, Trends Biomater. Artif. Organs. 5 (18): 2-4.

Perwitasari, D.S., 2008. Hidrolisis Tulang Sapi Menggunakan $\mathrm{HCl}$ untuk Pembuatan Galatin, Penggolahan Sumber Daya Alam dan Energi Terbarukan. Prosiding Seminar Nasional Soebardjo Brotohardjono. " Pengolahan Sumber Daya Alam Dan Energi Terbarukan ".Surabaya, 18 Juni 2008. HIm. C10-1 - C10-9.

Pinangsih AC., Wardhani S., Darjito. 2014. Sintesis Biokeramik Hidroksiapatit $\left(\mathrm{Ca}_{10}\left(\mathrm{PO}_{4}\right)_{6}(\mathrm{OH})_{2}\right)$ dari limbah tulang sapi menggunakan metode sol-gel. Kimia Student Journal. 1(2): 203209.

Purnama EF., S Nikmatin., R Langenati. 2006. Pengaruh Suhu Reaksi Terhadap Derajat Kristalinitas dan 
Komposisi Hidroksiapatit Dibuat Dengan Media Air Dan Cairan Tubuh Buatan (Synthetic Body Fluid). Jurnal Sains Materi Indonesia. Edisi Khusus Oktober : 153-162.

Vaidya, S. N., C Karunakaran., M Pande., M Gupta., K lye., B Karweer. 1997. Pressure-induced crystalline to amorphous transition in hydroxyapatite. Journal of Materials Science. 32 (12): 3213-3217.

Vijayalakshmi U, Rajeswari S. 2006. Preparation and characterization of microcrystalline hydroxiapatite using sol gel method. Trends Biomater Artificial Organs. 19(2): 57-62.

Wathi A.F.D., W Sri., M.K Mohammad. 2014. Pengaruh Perbandingan Massa Ca:P Terhadap Sintesis Hidroksiapatit Tulang Sapi Dengan Metode Kering. Kimia Student Journal. 1(2):196-202.

Wahdah l'anatul, W. S. Darjito. 2014. Sintesis Hidroksiapatit Dari Tulang Sapi Dengan Metode BasahPengendapan. Kimia Student Journal. 1(1): 92-97. 